Original Article

\title{
Study of microstructure, geometry and properties of laser beam welded joints made of S960QL structural steel and 3304 corrosion-resistant steel
}

\author{
Piotr Śliwiński ${ }^{*}$, Maciej Piotrowski ${ }^{2}$ \\ 1 Łukasiewicz Research Network - Institute of Welding, Poland \\ 2 Silesian University of Technology; Poland piotrowski.maciej.pm@gmail.com \\ * Correspondence: piotr.sliwinski@is.gliwice.pl \\ Received: 17.11.2020; Accepted: 30.12.2020
}

\begin{abstract}
Contemporary grades of structural steels are produced using a very advanced thermomechanical treatment processes, so their properties strongly depend on the obtained structure. Corrosion-resistant austenitic steels have a high hot cracking tendency. Therefore, it is advantageous to use welding technologies, such as laser welding, that limit the size of the joint and its heat-affected zones and thus the deformations caused by the welding process. Laser welding is also characterized by small amount of heat transferred into the material during the process which limits the hot cracking tendency. During the tests, 8 samples made of S960QL steel and S304 steel, were prepared using a Trumpf TruDisk 3302 laser welding device. The produced samples were subjected to macro- and microscopy metallographic tests. Static tensile test and bend test were also performed as well as a hardness Vickers test under a load of $100 \mathrm{~N}$. Good quality joints were obtained, characterized by a small number of welding imperfections. All passed the tensile test, the rupture occurred in the base material of S304 steel. All joints passed the bend test. The hardness of the welded joints ranged from 430-480 HV.
\end{abstract}

Keywords: laser welding; structural steel; stainless steel; dissimilar joint.

\section{Introduction}

Joining dissimilar materials has always been a challenge for engineers. Joints of this type frequently used in industrial applications are corrosion resistant steel joints with structural steels. Different chemical composition and microstructure, other mechanical properties and the potential formation of electrochemical corrosion are significant problems when designing this type of joint [1].

Due to the fact that the laser radiation is coherent and monochromatic, and the beam has a minimum discrepancy, it is possible to highly concentrate the radiation and obtain a very high energy density in a precisely selected area. Welding with high energy density makes it possible to obtain the appropriate penetration depth while introducing less heat to the material. This reduces the occurrence of hot cracking phenomena in susceptible materials such as corrosion resistant austenitic steels. In the case of materials whose properties strongly depend on the microstructure resulting from heat and plastic treatment, such as S960QL steel, welding with a laser beam allows to obtain a very narrow HAZ, and therefore favors a slight reduction in strength properties $[2 \div 5]$.

S960QL steel is weldable, and laser-welded joints are characterized by correct geometry, symmetry,

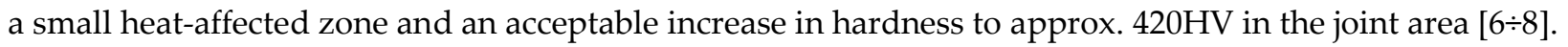

The AISI 304 (1.4301) grade is characterized by good weldability using the laser welding method. As in the case of S960QL steel, the joints have the correct geometry, they are also characterized by negligible influence of the welding process on the hardness in the joint area. The microstructure of similar joints of AISI 304 steel is austenitic, however, it is also characterized by the presence of often significant amounts of $\delta$ ferrite in the area of the weld and the heat-affected zone [9-11]. Joining AISI 304 steel with steels that do not contain significant amounts of austenite-forming elements, such as nickel, causes the formation of a martensitic or martensitic-austenitic microstructure in the weld area, which may lead to a very large increase in hardness $[12,13]$.

The purpose of the work was to investigate the effect of welding parameters on the microstructure and strength properties of dissimilar welded joints made of S960QL structural steel and S304 corrosion-resistant steel made with a disk laser. 


\section{Steels used for the research}

S960QL steel is a fine grain structural steel with a high minimum yield point. It is a heat-treated steel with a bainitic-martensitic microstructure, which can operate at reduced temperatures. It is intended for heavily loaded structures and elements, also welded, including cranes, gantry cranes, mobile cranes, bridges, road machinery, as well as sluices and mining equipment [14]. Table I shows the chemical composition of S960QL steel.

Table I. Chemical composition of S960QL steel according to PN-EN 10025-6

\begin{tabular}{|c|c|c|c|c|c|c|c|c|c|c|c|c|c|c|}
\hline $\begin{array}{c}\mathrm{C} \\
{[\%]}\end{array}$ & $\begin{array}{l}\text { Mn } \\
{[\%]}\end{array}$ & Si [\%] & $\begin{array}{c}\mathbf{P} \\
{[\%]}\end{array}$ & $\begin{array}{c}\mathrm{S} \\
{[\%]}\end{array}$ & $\begin{array}{c}\mathrm{Cr} \\
{[\%]}\end{array}$ & $\begin{array}{c}\mathrm{Ni} \\
{[\%]}\end{array}$ & $\begin{array}{l}\text { Mo } \\
{[\%]}\end{array}$ & $\begin{array}{c}\text { Al } \\
{[\%]}\end{array}$ & $\begin{array}{c}\mathrm{V} \\
{[\%]}\end{array}$ & $\begin{array}{c}\mathrm{Ti} \\
{[\%]}\end{array}$ & $\begin{array}{c}\mathrm{Cu} \\
{[\%]}\end{array}$ & $\begin{array}{c}\mathrm{N} \\
{[\%]}\end{array}$ & $\begin{array}{c}\mathrm{Zr} \\
{[\%]}\end{array}$ & $\begin{array}{c}\text { B } \\
{[\%]}\end{array}$ \\
\hline Max & Max & & Max & Max & Max & Max & Max & Max & Max & Max & Max & Max & Max & Max \\
\hline 0.2 & 1.7 & & 0.02 & 0.01 & 1.5 & 2.0 & 0.7 & 0.05 & 0.12 & 0.05 & 0.5 & 0.015 & 0.15 & 0.005 \\
\hline
\end{tabular}

Grade S304 is one of the most popular corrosion-resistant steels that are used in a very wide range in industry. S304 steel is used in the construction of tanks and pipelines, but also in other structures such as cisterns, sluices or elements of devices operating in a corrosive environment. Table II below shows its chemical composition.

Table II. Chemical composition of S304 (1.4301) steel according to PN-EN 10088-1

\begin{tabular}{cccccccc}
\hline C [\%] & Mn [\%] & Si [\%] & P [\%] & S [\%] & Cr [\%] & Ni [\%] & N [\%] \\
\hline $\operatorname{Max}$ & $\operatorname{Max}$ & $\operatorname{Max}$ & $\operatorname{Max}$ & $\operatorname{Max}$ & \multirow{2}{*}{$17 \div 20$} & \multirow{2}{*}{$8 \div 11$} & $\operatorname{Max}$ \\
0.1 & 2 & 1 & 0.05 & 0.02 & & & 0.1 \\
\hline
\end{tabular}

This type of steel is also used in the chemical industry for heat exchangers, reactors, coolers and condensers, it is also used for food storage and processing, in the pulp and paper industry, shipbuilding and railways [15].

\section{Subject of the study}

The subject of the research were 8 dissimilar welded joints made of S960QL steel and S304 steel, made with the Trumpf TruDisk 3302 disk laser. The joints were made of metal sheets with dimensions of $75 \times 100 \mathrm{~mm}$ and a thickness of $4 \mathrm{~mm}$. Each of the welds was made with different process parameters, these parameters are listed in Table III.

Table III. Welding parameters for samples $1 \div 8$

\begin{tabular}{|c|c|c|c|c|c|c|c|c|}
\hline Sample No. & 1 & 2 & 3 & 4 & 5 & 6 & 7 & 8 \\
\hline Welding speed $[\mathrm{mm} / \mathrm{min}]$ & 2000 & 1800 & 1600 & 1400 & 900 & 800 & 700 & 600 \\
\hline Laser beam power $[\mathrm{kW}]$ & \multicolumn{5}{|c|}{3200} & \multicolumn{2}{|c|}{2400} & \\
\hline Beam focus length $[\mathrm{mm}]$ & \multicolumn{8}{|c|}{223} \\
\hline Beam focus diameter $[\mu \mathrm{m}]$ & \multicolumn{8}{|c|}{200} \\
\hline $\begin{array}{l}\text { Location of the focal point in relation to the joint's } \\
\text { surface }[\mathrm{mm}]\end{array}$ & \multicolumn{8}{|c|}{-1} \\
\hline Shielding gas flow rate (Argon) [1/min] & \multicolumn{8}{|c|}{18} \\
\hline
\end{tabular}

\section{Results}

\section{Macroscopic examinations and determination of the weld's geometry}

Samples with dimensions of $40 \times 14 \mathrm{~mm}$, cut from welded joints, were cold mounted and ground on a grinder-polisher to a gradation of 1200 . Then the samples were etched in an aqueous solution containing $5 \%$ nitric acid $\left(\mathrm{HNO}_{3}\right)$ and $5 \%$ hydrochloric acid $(\mathrm{HCl})$, and then the geometry of the welds was measured (Fig. 1). The width of the weld face, the width of the root, the width of the heat affected zone, as well as the incompletely filled groove or excessive penetration were measured. The measurement results are presented in Table IV. 


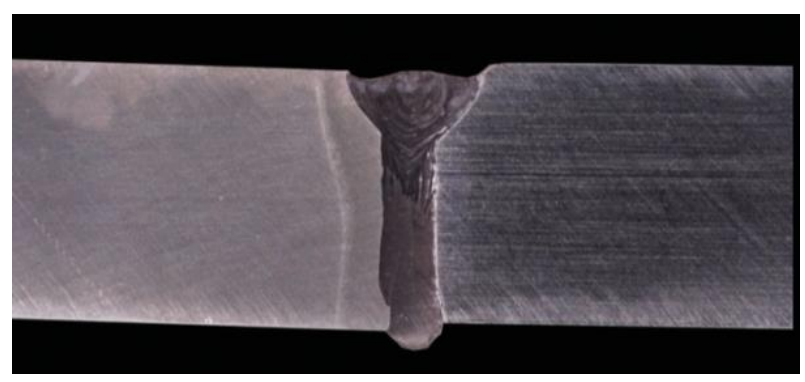

(1)

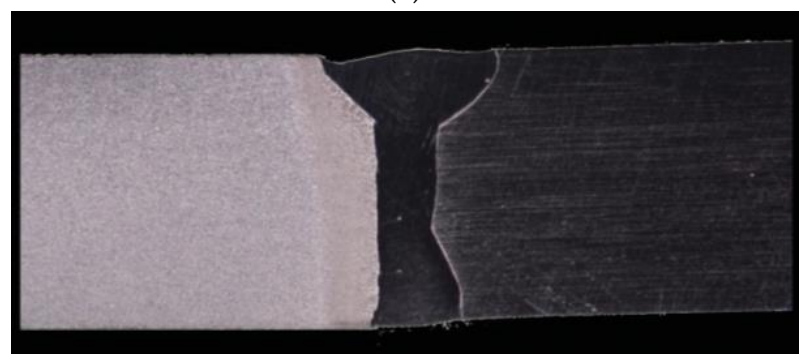

(3)

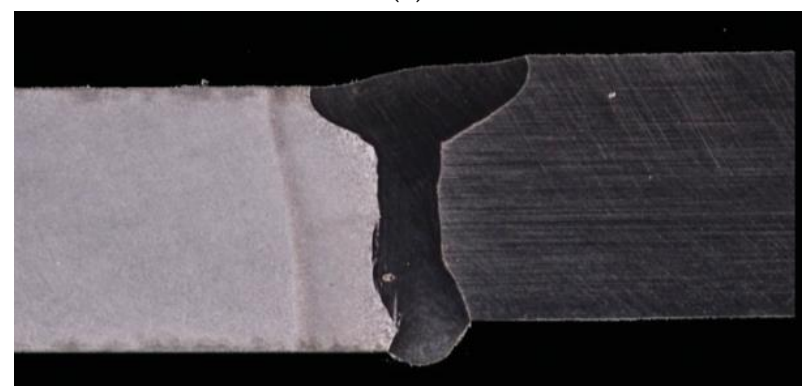

(5)

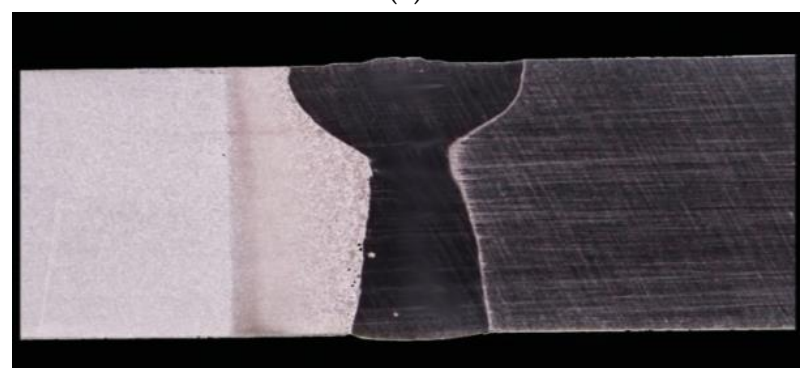

(7)

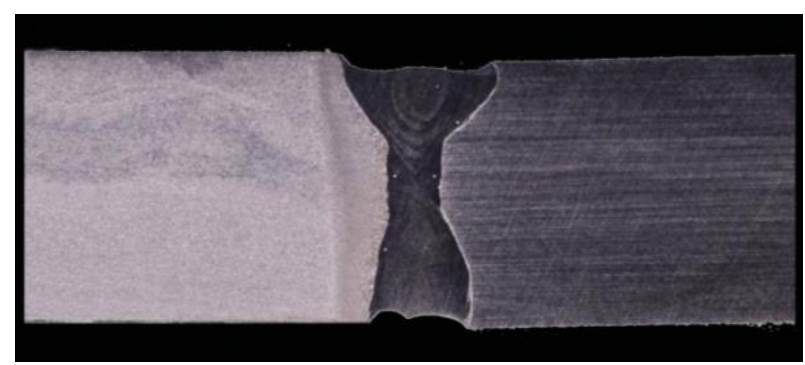

(2)

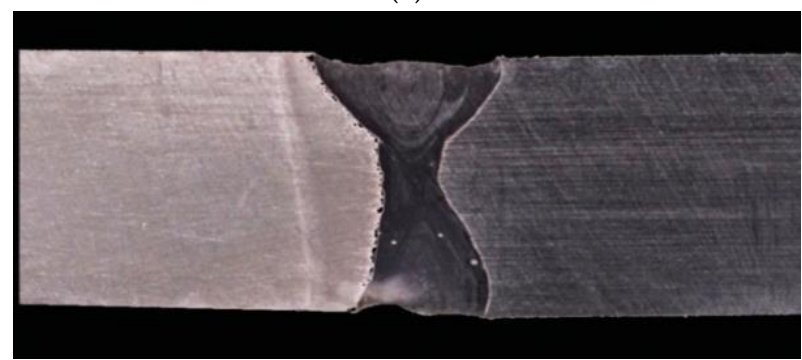

(4)

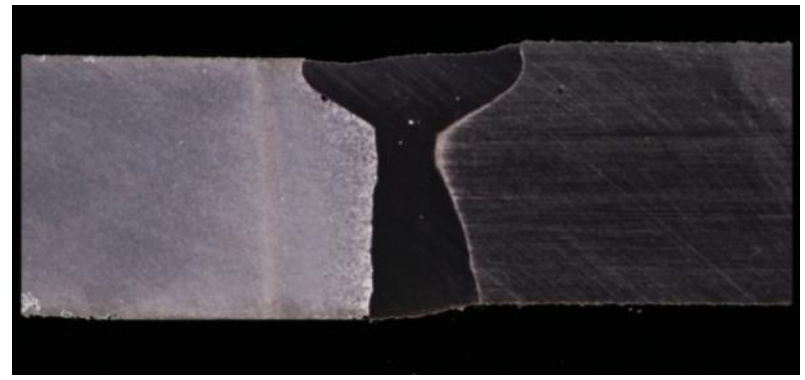

(6)

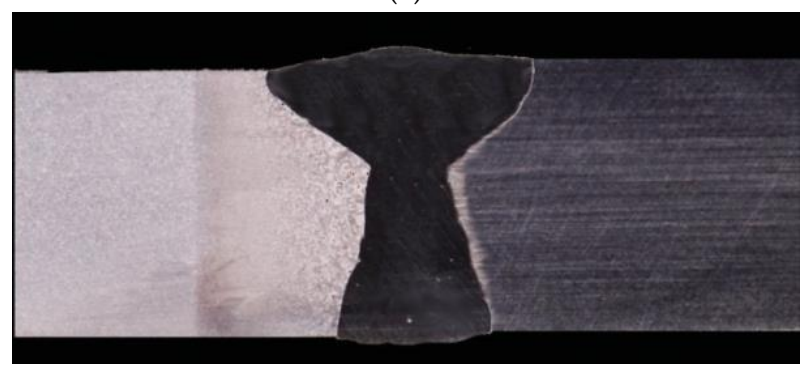

(8)

Fig. 1. Geometry of welded joints from samples $1 \div 8$

Table IV. Geometric dimensions of welds from samples $1 \div 8$

\begin{tabular}{ccccccccc}
\hline Sample No. & $\mathbf{1}$ & $\mathbf{2}$ & $\mathbf{3}$ & $\mathbf{4}$ & $\mathbf{5}$ & $\mathbf{6}$ & $\mathbf{7}$ & $\mathbf{8}$ \\
\hline Face width & 2,12 & 2,32 & 2,62 & 2,82 & 3,25 & 3,36 & 3,54 & 4,00 \\
Root width & 0,88 & 1,50 & 1,33 & 1,94 & 1,23 & 1,72 & 2,09 & 2,29 \\
Incompletely filled & $-0,18$ & $-0,29$ & $-0,09$ & $-0,20$ & 0 & $-0,06$ & 0 & 0,37 \\
groove & & & & & & & & \\
Excessive penetration & 0,38 & $-0,16$ & 0 & $-0,14$ & 0,21 & 0 & 0,08 & 0,22 \\
HAZ & 1,51 & 1,47 & 1,81 & 2,05 & 2,22 & 2,41 & 2,78 & 3,16 \\
\hline
\end{tabular}

Complete-penetration welds were obtained in each case. In the case of samples 5 and 6 , there is a linear shift of the plates, which has a significant impact on the geometry of the obtained welds. In the case of samples No. 3, 6 and 7, welds were obtained in which the incompletely filled groove and excessive penetration did not occur or were very small. A clear change in the geometry of each of the welds at a depth of $1 \mathrm{~mm}$ below the surface of the material is caused by the focus of the laser beam in this location. As a result, the width of the weld in this area is much greater than the width in the rest of the cross-section. 


\section{Microscopic examinations}

The mounted samples were ground and then polished with a $3 \mu \mathrm{m}$ diamond suspension. The samples from the side of S960QL steel were etched with 3\% Nital, and from the side of the weld and corrosionresistant steel, they were etched in an aqueous solution containing 5\% nitric acid $\left(\mathrm{HNO}_{3}\right)$ and $5 \%$ hydrochloric acid $(\mathrm{HCl})$. Microscopic examinations were performed on a Nikon Eclipse MA100 microscope using a Nikon DS-Fi2 camera.

Figure 2 shows the HAZ from the side of S960QL steel with a visible normalization zone, a grain growth zone and a martensitic microstructure at the fusion line. A significant increase of martensite grains was observed in sample No. 7 in relation to sample No. 2. Figure 3 shows a photo of the microstructure of the weld's center.

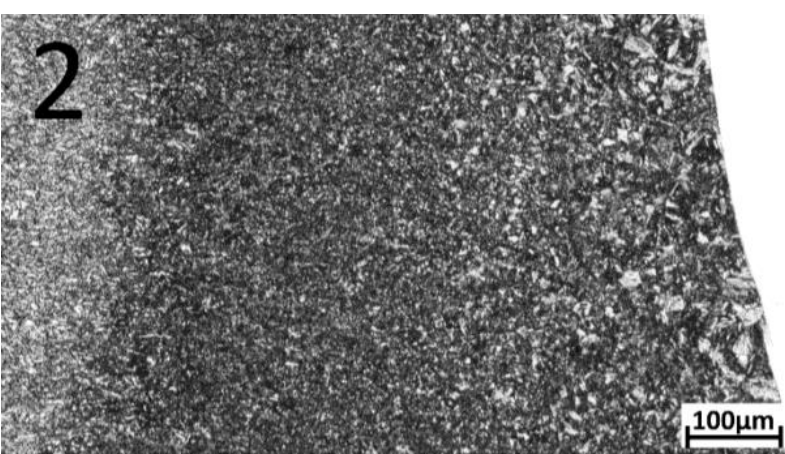

(a)

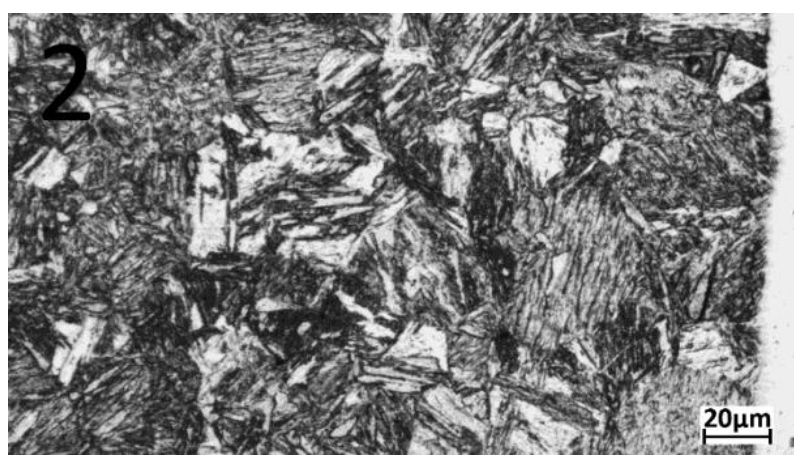

(c)

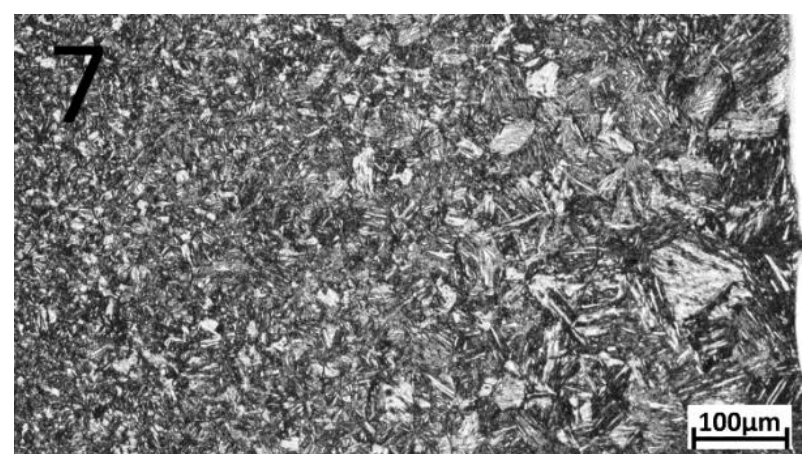

(b)

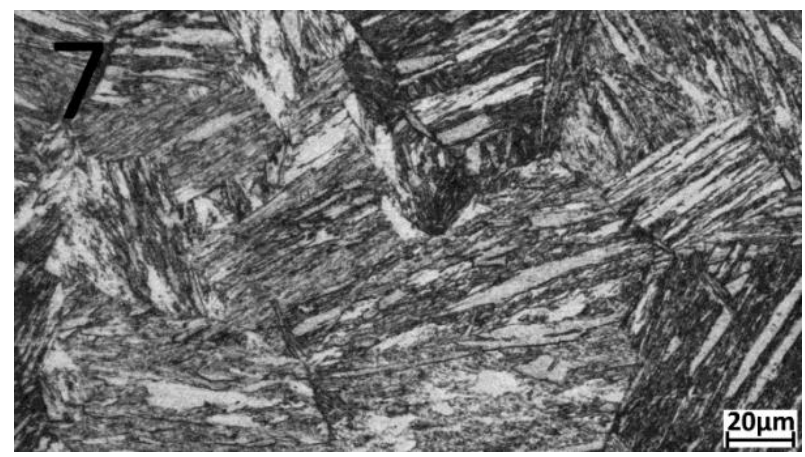

(d)

Fig. 2. Microstructure of the heat-affected zone in S960QL steel: a) sample No. 2, b) sample No. 7, c) magnification of sample No. 2, d) magnification of sample No. 7

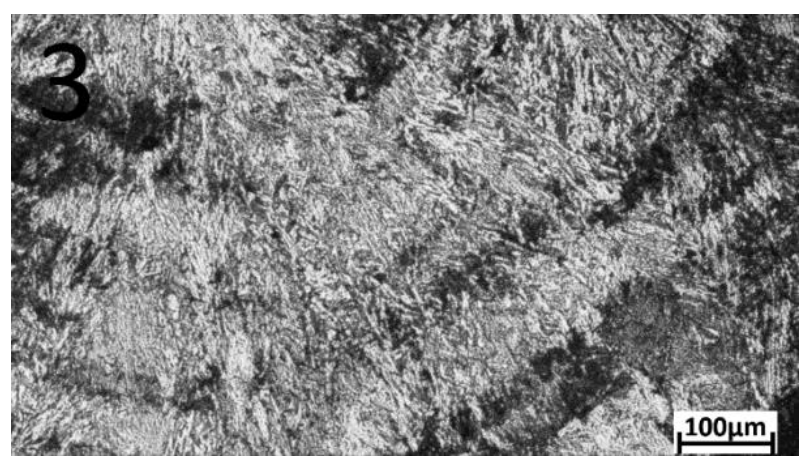

(a)

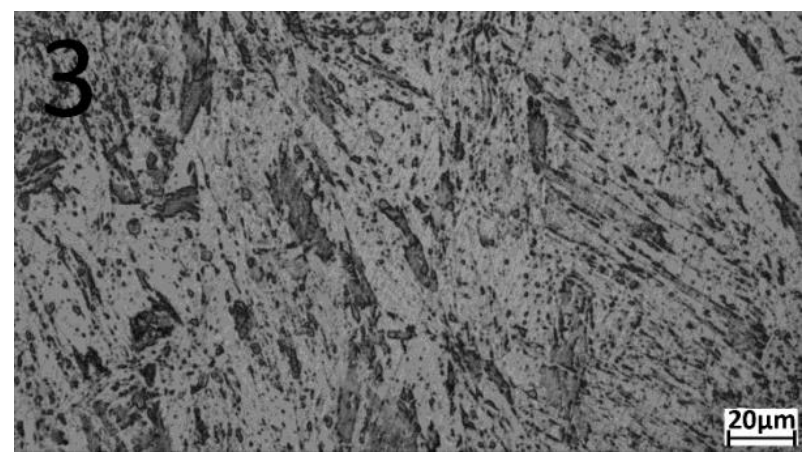

(b)

Fig. 3. Microstructure of the weld on the example of sample number 3

Figure 4 shows the heat-affected zone from the side of the S304 corrosion-resistant steel with austenitic microstructure. Figure 4a shows the heat-affected zone of sample No. 2 with a small amount of ferrite ( $\delta)$ precipitates right next to the fusion line, while in Figure $4 \mathrm{~b}$ there are extensive ferrite precipitations $(\delta)$ observed, among others in sample No. 7. Figure 5 shows the microstructure of the ferrite $(\delta)$ precipitates.

The microstructure present in the HAZ of S960QL steel is typical for welded joints of this type of steel, there is an overheating zone with a martensitic microstructure with a clear grain growth relative to the parent material, as well as a normalization zone with visible strong grain refinement. 


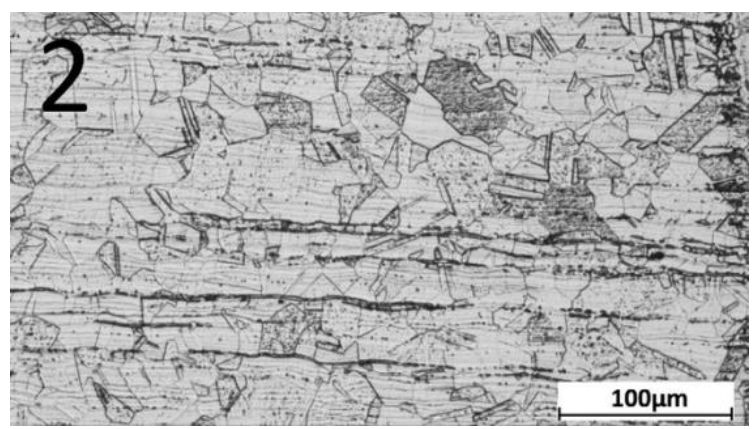

(a)

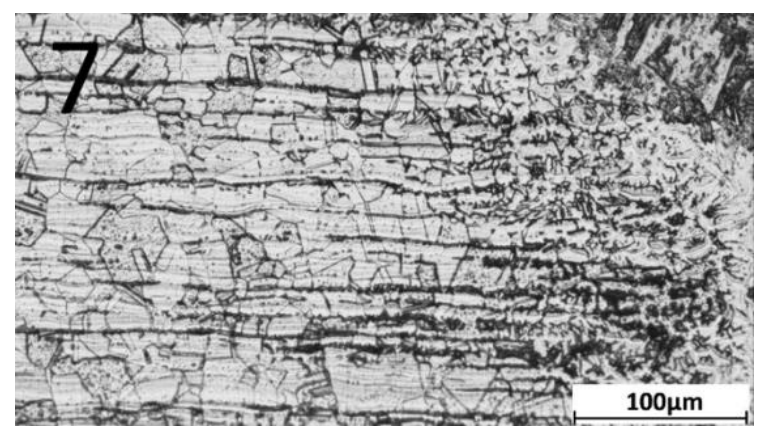

(b)

Fig. 4. Microstructure of the heat affected zone on the side of S304 steel: a) sample number 2 with a small amount of ferrite precipitates $(\delta) ; b)$ sample number 7

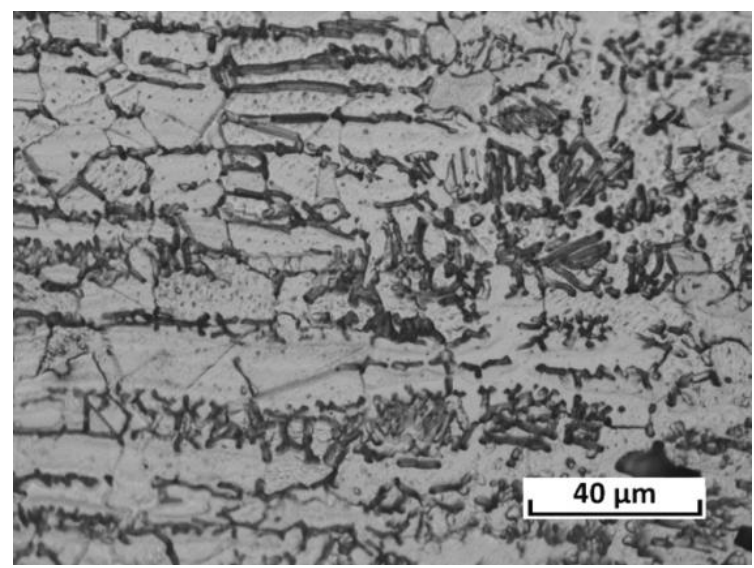

(a)

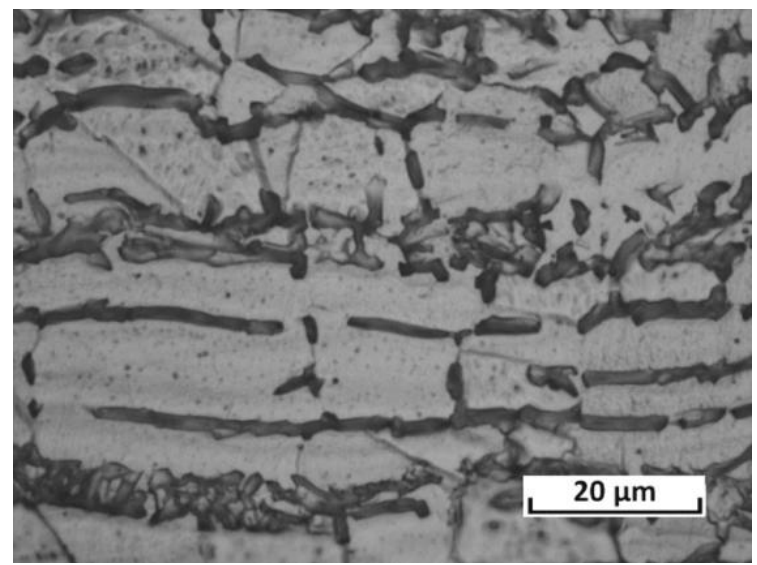

(b)

Fig. 5. The microstructure of ferrite precipitates $(\delta)$ on the example of sample number 8

In the case of austenitic steel, there was no grain growth in the HAZ, however, precipitation of $\delta$ ferrite with a characteristic microstructure appeared. Their highest concentration occurs at the fusion line.

The Schaeffler's diagram (Fig. 6) was used to determine the phase composition of the weld. Equivalents of nickel and chromium were calculated for both steels used in the process and $50 \%$ mixing of the parent material was assumed. The obtained result corresponds to the microstructure of high-alloy martensite with the participation of austenite visible in microscopic photos.

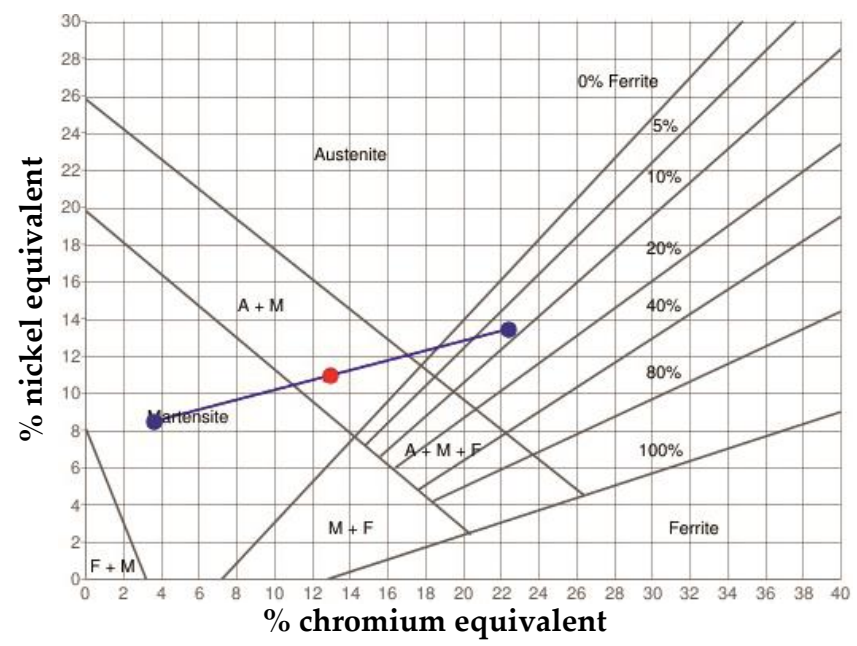

Fig. 6. Determination of the phase composition using the Schaeffler's diagram

\section{The effect of heat input on the microstructure and geometry of welds}

In order to determine the effect of heat input on the microstructure and geometry of the obtained welds in the tested joint, the following measurements were taken into account for the S960QL steel: the general width of the heat affected zone measured during macroscopic tests and the average size of the martensite grain at the fusion line, while for austenitic steel: the average width of the ferrite $\delta$ occurrence 
zone, because there was no grain growth in its microstructure. Each sample was measured three times and the average was calculated. Table $V$ shows the measured values. Figure 7 shows the graphs determining the dependence of the measured values on the heat input of welding. The heat input was calculated from the formula (1):

$$
E=\frac{P}{v}
$$

where:

E - heat input $[\mathrm{kJ} / \mathrm{mm}]$;

$\mathrm{P}$ - beam power $[\mathrm{W}]$

$\mathrm{v}$ - welding speed $[\mathrm{mm} / \mathrm{min}]$.

Table V. The results of measurements of the martensite grain size, the width of the HAZ from the S960QL steel side and the average width of the $\mathrm{Fe}(\delta)$ occurrence zone

\begin{tabular}{ccccc}
\hline $\begin{array}{c}\text { Sample } \\
\text { No. }\end{array}$ & $\begin{array}{c}\text { Heat input } \\
{[\mathbf{k J} / \mathbf{m m}]}\end{array}$ & $\begin{array}{c}\text { HAZ width of } \\
\text { S960QL }[\mathbf{m m}]\end{array}$ & $\begin{array}{c}\text { Average size of martensite } \\
\text { plates at the fusion line }[\mu \mathrm{m}]\end{array}$ & $\begin{array}{c}\text { Average width of the } \\
\text { Fe }(\delta) \text { zone }[\mu \mathrm{mm}]\end{array}$ \\
\hline 1 & 96.0 & 1.51 & 18.7 & 50.8 \\
2 & 106.7 & 1.47 & 20.8 & 30.0 \\
3 & 120.0 & 1.81 & 30.0 & 15.0 \\
4 & 137.1 & 2.05 & 34.0 & 83.3 \\
5 & 160.0 & 2.22 & 38.3 & 16.7 \\
6 & 180.0 & 2.41 & 54.0 & 150.0 \\
7 & 205.7 & 2.78 & 76.4 & 166.7 \\
8 & 240.0 & 3.16 & 85.1 & 244.8 \\
\hline
\end{tabular}

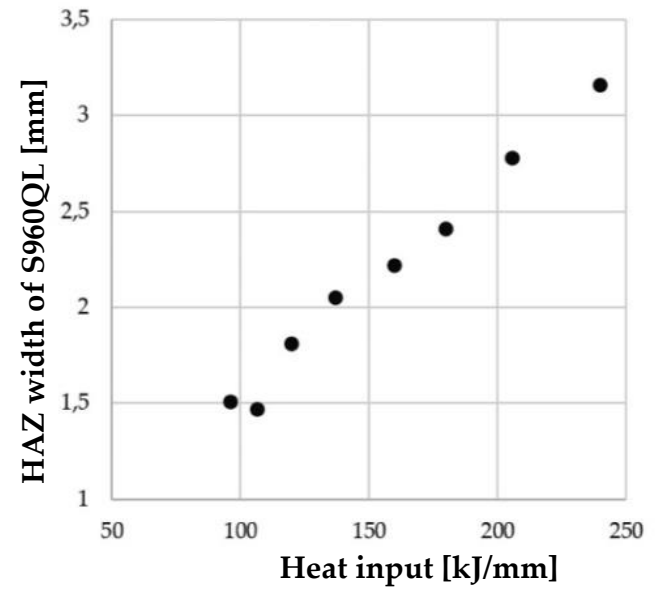

(a)

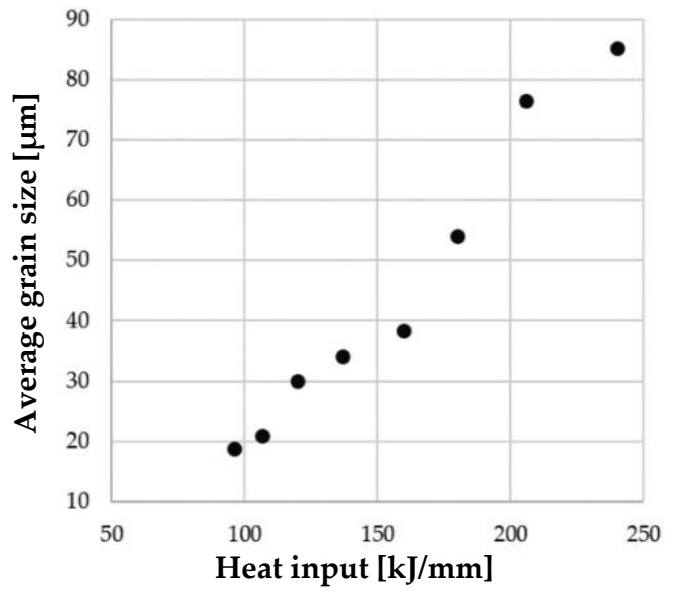

(b)

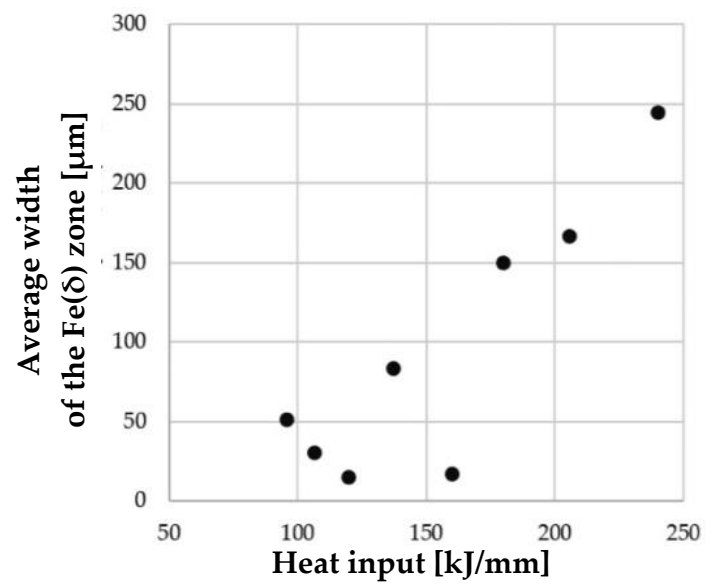

(c)

Fig. 7. a) Graph of the dependence of the HAZ width on the heat input of welding; b) Graph of the dependence of the average size of martensite grain on the heat input of welding; c) Diagram of dependence on average Fe( $\delta$ ) zone width on the heat input of welding 


\section{Hardness measurements}

For each of the samples, the hardness of the base material (BM) and the heat-affected zone (HAZ) were measured on both sides, as well as the weld. Five measurements were made, the highest values and the lowest were discarded, the others were averaged and presented in Table VI.

Table VI. Average hardness test results

\begin{tabular}{cccccc}
\hline \multirow{2}{*}{ Sample } & \multicolumn{2}{c}{ S960QL } & Weld & HAZ & BM \\
\hline 1 & 335 & 441 & 438 & 187 & 177 \\
2 & 332 & 454 & 454 & 189 & 175 \\
3 & 333 & 431 & 480 & 195 & 176 \\
4 & 338 & 422 & 469 & 181 & 176 \\
5 & 332 & 432 & 437 & 195 & 176 \\
6 & 332 & 412 & 479 & 189 & 176 \\
7 & 335 & 424 & 456 & 181 & 173 \\
8 & 339 & 409 & 431 & 178 & 175 \\
\hline
\end{tabular}

\section{Bending tests}

A static bending test was performed for all joints. Samples with the dimensions of 100x16x4 mm were cut and tested on a mandrel with a diameter of $16 \mathrm{~mm}$. A bending angle of $130^{\circ}$ was achieved. None of the samples were damaged, there were no cracks on the face side, and the continuity of the material was not broken.

\section{Tensile tests}

Tensile tests were performed using the Zwick Roell Z060 machine. All samples broke in the base material on the side of the S304 corrosion-resistant steel. Table VII shows the test results for each joint. Figure 8 shows an example of a static tensile test graph for sample No. 3 .

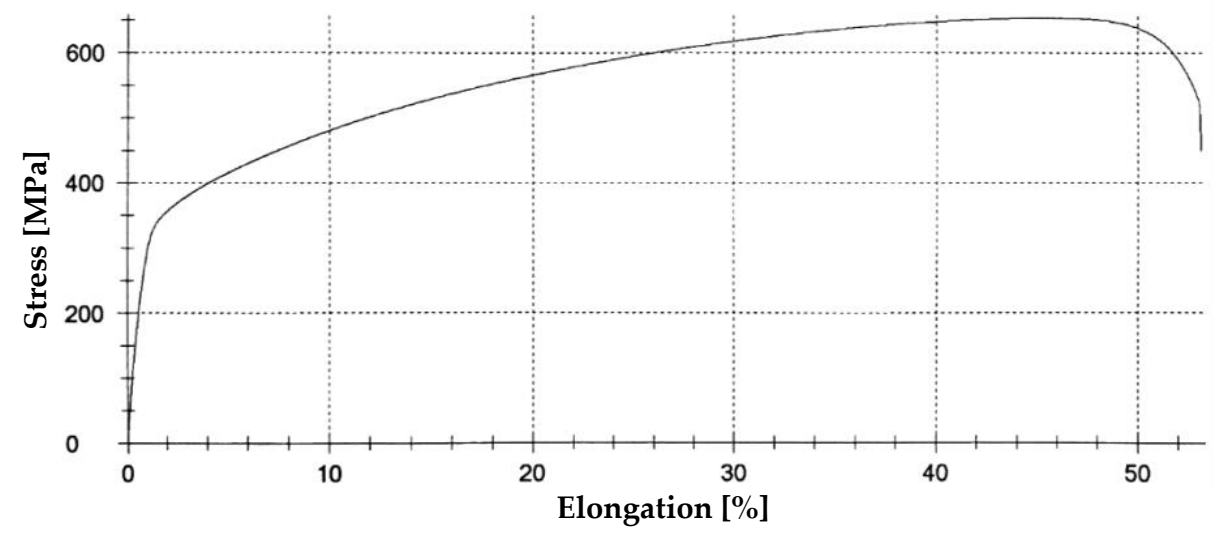

Fig. 8. Graph of the tensile test of sample No. 3

Table VII. Results of the performed tensile test

\begin{tabular}{ccccccccc}
\hline $\begin{array}{c}\text { Sample } \\
\text { No. }\end{array}$ & $\begin{array}{c}\mathbf{b}_{0} \\
{[\mathbf{m m}]}\end{array}$ & $\begin{array}{c}\mathbf{a}_{0} \\
{[\mathbf{m m}]}\end{array}$ & $\begin{array}{c}\mathbf{S}_{0} \\
{[\mathbf{m m} 2]}\end{array}$ & $\begin{array}{c}\mathbf{L} 0 \\
{[\mathbf{m m}]}\end{array}$ & $\begin{array}{c}\mathbf{F}_{\mathbf{m}} \\
{[\mathbf{k N}]}\end{array}$ & $\begin{array}{c}\mathbf{R}_{\mathbf{m}} \\
{[\mathbf{M P a}]}\end{array}$ & $\begin{array}{c}\mathbf{F p}_{0,2} \\
{[\mathbf{k N}]}\end{array}$ & $\begin{array}{c}\mathbf{R}_{\mathbf{p} 0,2} \\
{[\mathbf{M P a}]}\end{array}$ \\
\hline 1 & 16.2 & 4.05 & 65.61 & 50 & 41.35 & 630 & 11.26 & 172 \\
2 & 15.9 & 4 & 63.6 & 50 & 40.68 & 640 & 10.42 & 164 \\
3 & 17.5 & 4 & 70 & 50 & 44.72 & 639 & 14.24 & 203 \\
4 & 16.14 & 4.05 & 65.37 & 50 & 41.03 & 628 & 13.42 & 205 \\
5 & 17.15 & 4 & 68.6 & 50 & 44.82 & 653 & 13.65 & 199 \\
6 & 16.8 & 4 & 67.2 & 50 & 43.02 & 640 & 13.6 & 202 \\
7 & 16.25 & 4 & 65 & 50 & 41.13 & 633 & 11.4 & 175 \\
8 & 16.3 & 4 & 65.2 & 50 & 42.5 & 652 & 12.46 & 191 \\
\hline
\end{tabular}




\section{Conclusions}

As the heat input increases, both the width of the weld itself and the heat-affected zone grows. An increase in the size of the martensite grain is also visible in the overheat zone of the S960QL steel. The ferrite $\delta$ zone width in the corrosion-resistant steel showed a linear increase for samples welded with the $2400 \mathrm{~W}$ beam at lower welding speeds, however it showed no increase for samples welded with the $3200 \mathrm{~W}$ beam and higher process speeds.

In the HAZ of austenitic corrosion-resistant steel, no grain growth was noted, however microscopic examinations showed an increased (in relation to the microstructure of the parent material) presence of $\delta$ ferrite, which may affect the properties of this joint area. The slight increase in hardness in this area is probably also due to the presence of this phase in the microstructure.

The performed hardness measurements show an increase in the HAZ hardness for S960QL steel and the weld. This is due to the presence of a martensitic microstructure. The hardness of both the weld and the HAZ in both materials shows no dependence on the heat input and its effect on the microstructure and geometry of the joint.

The results of the bending tests allow the conclusion that the weld and the HAZ do not show significant brittleness, and exposure of the joint to static bending moments will probably not lead to its destruction, but only to bending in the material of the lowest stiffness, i.e. in the area of the austenitic steel parent material.

The results of the static tensile tests show that the tensile strength of the joint is equal to the tensile strength of the material of AISI S304 corrosion-resistant steel.

On the basis of the conducted tests, it can be concluded that the laser welding technology is suitable for making dissimilar joints of austenitic corrosion-resistant steels and non-alloy structural steels of increased strength.

Author Contributions: conceptualization Ś.P.; methodology Ś.P., P.M.; validation Ś.P., P.M.; formal analysis Ś.P., P.M.; investigation Ś.P.; resources Ś.P.; data curation S.P., P.M.; writing-original draft preparation S.P.; writing - review and editing P.M.; visualization Ś.P., P.M.; supervision Ś.P.; project administration Ś.P., P.M.

\section{References}

1. Klueh R. L., King J. F., Austenitic stainless steel-ferritic steel weld joint failures. Welding Journal, 1982, 61.9, 302311.

2. Banasik M., Dworak J., Spawanie elektronowe i laserowe - Podręcznik inżyniera, Spawalnictwo, Tom 2. Wydanie pierwsze, pod red. J. Pilarczyka. Wydawnictwo Naukowo Techniczne, Warszawa 2018. ISBN 978-83-01-19180-1

3. Wyszyński D. (2016). Spawanie laserowe - wybrane metody. Welding Technology Review, 2016, Vol. 88(12). https://doi.org/10.26628/wtr.v88i12.717

4. Löffler K., 4 - Developments in disk laser welding, In Handbook of Laser Welding Technologies, Woodhead Publishing Series in Electronic and Optical Materials, 2013, 73-102, https://doi.org/10.1533/9780857098771.1.73.

5. Sun Z., Ion J. C., Laser welding of dissimilar metal combinations. Journal of Materials Science, 1995, 30.17, 42054214.

6. Ślęzak T., Śnieżek L., Properties of welded joints made in high strength steel using laser technology. Biuletyn WAT, 2017, Vol. LXVI, Nr 1. DOI: 10.5604/01.3001.0009.9484

7. Kurc-Lisiecka A., Lisiecki A. Laser welding of the new grade of advanced high-strength steel domex 960. Materiali in tehnologije/Materials and technology, 2017, Vol. 51(2), 199-204, DOI: 10.17222/mit.2015.158

8. Tuz L., Evaluation of Microstructure and Selected Mechanical Properties of Laser Beam Welded S690QL HighStrength Steel. Advances in Materials Science, 2017, Vol. 18, 34-42. 10.1515/adms-2017-0039.

9. Lisiecki A., \& Kurc-Lisiecka A., Automated laser welding of AISI 304 stainless steel by disk laser. Archives of Metallurgy and Materials, 2018, Vol. 63. DOI: 10.24425/amm.2018.125091

10. Hafez K. M., Katayama S., Fiber laser welding of AISI 304 stainless steel plates. Quarterly journal of the japan welding society, January 2009. DOI: 10.2207/qjjws.27.69s

11. Mousavi S. A. A. A., Gharedaghi A., Mastoori, M., Metallurgical Investigations of Laser Welding of AISI 304 Stainless Steel. Materials Science Forum, 2008, Vols. 580-582, 41-44. https://doi.org/10.4028/www.scientific.net/msf.580-582.41

12. Berrettaa J. R., de Rossib W., das Nevesc M. D. M., de Almeidab I. A., Vieira Junior N. D. Pulsed Nd:YAG laser welding of AISI 304 to AISI 420 stainless steels. Optics and Lasers in Engineering, 2007, Volume 45, Issue 9, 960-966, ISSN 0143-8166 
13. Ghusoon R. M. A., Mahadzir I., Hassan A. A. Fiber laser welding of dissimilar 2205/304 stainless steel plates. Metals, 2017, Vol. 7.12, 546.

14. Karta produktowa stali S960QL firmy STRENX Performance Steel. „Data sheet 2013 Strenx 960 2017-04-20”, URL: https://www.ssab.pl/produkty/marki/strenx/products/strenx-960-e-f (dostęp 15.05.2020)

15. Materiały dotyczące stali S304 firmy Alfa-tech, URL: https://www.alfa-tech.com.pl/stale-wysokostopowe-ospecjalnych-wlasnosciach-stal-kwasoodporna-0h18n9 (Dostęp 15.05.2020)

(C) 2021 by the authors. Submitted for possible open access publication under the terms and conditions of the Creative Commons Attribution (CC BY) license (http://creativecommons.org/licenses/by/4.0/). 